\title{
Flavin metabolism during respiratory infection in mice
}

\author{
BY SANGEETHA BRIJLAL, A. V. LAKSHMI*, MAHTAB S. BAMJI \\ AND P. SURESH \\ Department of Biochemistry, National Institute of Nutrition, Jamai Osmania, \\ Hyderabad-500 007, India
}

(Received 3 July 1995 - Revised 6 November 1995 - Accepted 21 December 1995)

\begin{abstract}
Previous control studies carried out in children showed that respiratory infection alters riboflavin metabolism and leads to excessive urinary losses of the vitamin. In order to understand the nature of biochemical changes in riboflavin metabolism during respiratory infection, a study was carried out using the mouse as the experimental model, and Klebsiella pneumoniae as the infective organism. Mice were fed on either a low $(0.5 \mathrm{mg} / \mathrm{kg})$ - or high( $13.3 \mathrm{mg} / \mathrm{kg})$-riboflavin semi-synthetic diet. Infection resulted in a 5-6-fold higher excretion of riboflavin in the urine of mice fed on the low-riboflavin diet. Higher erythrocyte FAD levels and lower liver FAD levels were also observed during infection. Of the four enzymes involved in the synthesis and breakdown of the flavin coenzymes studied, the activity of hepatic flavokinase (ATP: riboflavin $5^{\prime}$-phosphotransferase; $E C$ 2.7.1.26) was significantly lower, and that of FAD synthetase (ATP: FMN adenylyltransferase; EC 2.7.7.2) was higher during riboflavin restriction and infection. The activity of FMN (acid) phosphatase $(E C 3.1 .3 .2)$ was unchanged, whereas FAD (nucleotide) pyrophosphatase ( $E C$ 3 6.1 .9 ) activity was significantly higher both with the low-riboflavin diet and during infection. Thyroid hormone is known to modulate flavokinase activity and, hence, thyroid status was assessed. Plasma triiodothyronine (T3) levels were not affected, but thyroxine levels were lower in the mice fed on the low-riboflavin diet. However, plasma T3 was significantly lower during infection, suggesting a mechanistic role for the hormone in the reduction of flavokinase activity.
\end{abstract}

Riboflavin: Respiratory infection

Studies in developing countries, for example India, have revealed a very high incidence of biochemical riboflavin deficiency, particularly in women and children, as judged by the activation of erythrocyte glutathione reductase (EC 1.6.4.2; EGR) with its coenzyme, FAD (Thurnham et al. 1971; Bamji et al. 1979, 1981, 1982; Bates et al. 1981; World Health Organization Task Force and Oral Contraceptives, 1986). Investigations carried out with children suggest that the aetiology of riboflavin deficiency in this population may be more complex, and apart from low dietary intake of riboflavin, repeated respiratory infections may also play a role (Bamji et al. 1982).

A control study carried out using children with respiratory infection showed an increase in erythrocyte and urinary levels of riboflavin and a decrease in values for EGR activation coefficient (stimulated : basal activity; AC). However, after recovery from infection there was a deterioration in riboflavin status, as judged by the previously mentioned variables (Bamji et al. 1987). Similar changes in erythrocyte riboflavin and EGR-AC values were observed in a study carried out using mice infected with Klebsiella pneumoniae (Padmaja et al. 1991). In this study also there were changes in the activities of the riboflavindependent hepatic enzymes, acyl-CoA dehydrogenase $(E C 1$ 1.3.99.3) and pyridoxaminephosphate oxidase (EC 1.4.3.5).

\footnotetext{
* For reprints.
} 
The objective of the present study was to determine whether the increase in blood and urinary levels of riboflavin observed during infection is due to changes in the synthesis and/or breakdown of the riboflavin coenzymes, FMN and FAD. The investigation was carried out in mice using Klebsiella pneumoniae as the infective organism. Activities of the enzymes involved in the synthesis and breakdown of riboflavin coenzymes (FMN and FAD) were measured in the liver during infection and after recovery.

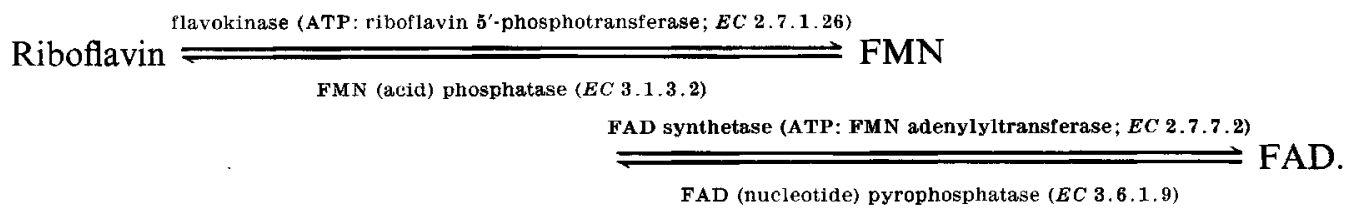

Total flavins, free riboflavin, FMN and FAD levels in the erythrocytes and liver, and urinary excretion of riboflavin were also measured.

Since thyroid hormone is known to influence riboflavin metabolism by modulating flavokinase activity (Rivlin \& Langdon, 1966; Lee \& McCormick, 1985), thyroid-hormone status of the animals was assessed during infection and after recovery.

\section{MATERIALS AND METHODS}

Male weanling mice (128) of the Swiss/NIN strain (mean body weight $12 \mathrm{~g}$ ) were divided equally into low- and high-riboflavin groups. The animals were housed individually in screen-bottomed cages. Care was taken to maintain the animals at optimal temperature $\left(22-25^{\circ}\right)$ and humidity $(55 \pm 10 \%)$, and a $12 \mathrm{~h}$ light-dark cycle. They were fed ad libitum on a purified diet containing $(\mathrm{g} / \mathrm{kg})$ : sucrose 700 , vitamin-free casein (Sigma Chemical Co., St Louis, MO, USA) 200, peanut oil 50, salt mixture 40 and vitamin mixture 10 . The composition of the salt and vitamin mixtures was that described previously by Lakshmi et al. (1994). The riboflavin content of the low-riboflavin diet was $0.5 \mathrm{mg} / \mathrm{kg}$. This level of riboflavin would be expected to simulate the human situation in developing countries where riboflavin is one of the limiting nutrients. The high-riboflavin diet contained $13.3 \mathrm{mg}$ riboflavin $/ \mathrm{kg}$.

After $18 \mathrm{~d}$ of feeding the mice with the experimental diets, thirty-two animals in each group were infected with a sub-lethal dose $\left(6 \cdot 15 \times 10^{6}\right.$ cells) of Klebsiella pneumoniae in $0.5 \mathrm{ml}$ distilled water administered intraperitoneally. At this dose no deaths were observed in preliminary experiments carried out to determine the $50 \%$ lethal dose. The organism was isolated from the lung of the rat (NIN/WISTAR strain) and purified. The remaining mice in both groups received the same amount of distilled water intraperitoneally and they served as uninfected controls. Mice were kept in metabolism cages and urine was collected over toluene for $72 \mathrm{~h}$.

At $72 \mathrm{~h}$ after injection the infected animals showed signs of acute infection, such as loss of appetite and reddening of the snout. At this stage, half the number of animals in the lowand high-riboflavin, uninfected and infected groups were killed by decapitation after withdrawing a sample of blood from the ocular plexus. The remaining animals were killed $15 \mathrm{~d}$ later when the infected animals had recovered completely. The liver was perfused with cold saline $(9 \mathrm{~g} \mathrm{NaCl} / 1)$ to remove blood completely and then excised. Due to the paucity of material from a single mouse, blood, urine and tissues respectively of two animals from each group were pooled for a single sample. An homogenate $(200 \mathrm{mg} / \mathrm{ml})$ in potassium phosphate buffer (50 mM), pH 7.4, (prepared from 50 mu- $\mathrm{K}_{2} \mathrm{HPO}_{4}$ and $50 \mathrm{~mm}-\mathrm{KH}_{2} \mathrm{PO}_{4}$ ) was prepared using a Potter-Elvehjem homogenizer.

Samples (erythrocytes and liver) for HPLC analysis were prepared according to the 
method of Batey \& Eckhert (1990) and the analysis for free riboflavin, FMN and FAD by the method of Ohkawa et al. (1983).

Erythrocyte and liver free riboflavin, FMN and FAD levels were measured by HPLC using fluorescence detection and a Shimadzu (Kyoto, Japan) LC-6A system with two pumps. Separation was carried out on a reversed-phase column (ODS; Showa, Denko K. K., Tokyo, Japan) of size $4.6 \mathrm{~mm} \times 250 \mathrm{~mm} ; 5 \mu \mathrm{m}$ particle size. A guard column was used to protect the column. The solvents used were: A methanol, B methanol in $10 \mathrm{~mm}-$ $\mathrm{NaH}_{2} \mathrm{PO}_{4}, \mathrm{pH} 5 \cdot 5,(300 \mathrm{ml} / 1)$; the buffer was filtered, mixed with methanol and degassed just before use. Elution was carried out using a linear gradient rising from $300 \mathrm{ml}$ solvent $\mathrm{B} /$ litre solvent $\mathrm{A}$ to $860 \mathrm{ml}$ solvent $\mathrm{B} /$ litre solvent $\mathrm{A}$ within $8 \mathrm{~min}$, and this condition was maintained for $5 \mathrm{~min}$. The flow-rate was $0.8 \mathrm{ml} / \mathrm{min}$. The fluorescence intensities of the eluate were measured as excitation at $440 \mathrm{~nm}$ and emission at $530 \mathrm{~nm}$ using a Shimadzu RF-535 HPLC fluorescence spectrophotometer. The detector signal was recorded and the peak area quantified using a Shimadzu CR3A integrator. The retention times for free riboflavin, FMN and FAD were $8.0,5.7$ and $3.9 \mathrm{~min}$ respectively. The CV for this HPLC method for free riboflavin, FMN and FAD was $4 \cdot 2,3 \cdot 14$ and $4.6 \%$ respectively. The recoveries of the added free riboflavin, FMN and FAD ranged between 94 and $96 \%$.

The EGR-AC in erythrocytes was measured by the method of Bayoumi \& Rosalki (1976). Urinary riboflavin was measured fluorimetrically (Morell \& Slater, 1946).

\section{Enzyme assays}

Flavokinase. Flavokinase activity was determined in the $18500 \mathrm{~g}$ supernatant fraction from liver homogenate as described by Merrill \& McCormick (1980) with the following modifications: radioactive riboflavin was not used and the reaction time was $30 \mathrm{~min}$. FMN formed was quantified by the differential-extraction method of Kearney \& Englard (1951). Enzyme activity was expressed as nmol FMN formed $/ \mathrm{mg}$ protein per $30 \mathrm{~min}$ at $37^{\circ}$. The CV for the flavokinase assay was $5.02 \%$.

FAD synthetase. FAD synthetase activity was determined in the $100000 \mathrm{~g}$ supernatant fraction from liver homogenate according to the method of McCormick (1964). Quantification of FAD formed was done by the method of Ahmed et al. (1981) using apo D-amino acid oxidase (EC 1.4.3.3). Enzyme activity was expressed as nmol FAD formed $/ \mathrm{mg}$ protein per $60 \mathrm{~min}$ at $37^{\circ}$. The precision of enzyme assay was $4 \cdot 21 \%$.

FMN (acid) phosphatase. Preparation of the enzyme was similar to that for flavokinase assay. Incubation of the enzyme with FMN was carried out according to the method of McCormick (1961). Riboflavin formed was quantified by the differential-extraction method of Kearney \& Englard (1951). Enzyme activity was expressed as nmol riboflavin formed $/ \mathrm{mg}$ protein per $30 \mathrm{~min}$ at $37^{\circ}$. The CV for this method was $3 \cdot 2 \%$.

$F A D$ (nucleotide) pyrophosphatase. For reproducible quantification it was found necessary to purify the enzyme partially. A liver homogenate $(200 \mathrm{mg} / \mathrm{ml})$ was centrifuged at $800 \mathrm{~g}$ for $7 \mathrm{~min}$ to remove cell debris, and the supernatant fraction was centrifuged at $18000 \mathrm{~g}$ for $1 \mathrm{~h}$. The enzyme was partially purified from the pellet and assayed using FAD as substrate (Krishnan \& Appaji Rao, 1972). Enzyme activity was expressed as pmol FMN formed $/ \mathrm{mg}$ protein per min at $37^{\circ}$. The precision of this enzyme assay was $3.9 \%$.

Protein was estimated by the Folin-Lowry method (Lowry et al. 1951), urinary creatinine by the alkaline picrate method (Oser, 1965) and plasma triiodothyronine (T3) and thyroxine (T4) were measured using commercially-available kits from the Board of Radiation and Isotope Technology, Bombay, India. 


\section{Statistics}

Values are presented as means with their standard errors. Homogeneity of variances was tested using the Bartlett test. If this test was found to be significant $(P<0.05)$, then the actual values were transformed into logarithmic values and tested by means of ANOVA with the least significant difference (LSD) multiple-range test. One-way ANOVA was carried out for urinary riboflavin and erythrocyte free riboflavin, FMN and FAD. Specific differences were identified by the LSD multiple-range test at a significance level of $P<0.05$. The remaining results were compared by two-way ANOVA $(P<0.05)$ with the LSD multiple-range test (Snedecor \& Cochran, 1967).

\section{RESULTS}

There was a non-significant reduction in feed intake on days 1 and 2 after infection. Infection did not significantly affect body weights of the low- and high-riboflavin-fed groups. However, riboflavin restriction per se reduced weight gain (Table 1).

\section{Riboflavin, $F M N$ and $F A D$}

Urinary excretion of riboflavin was significantly higher in the high-riboflavin-fed group when compared with that of the low-riboflavin-fed group. Infection was associated with a 5-6-fold increase in urinary excretion of riboflavin in the low-riboflavin group (Table 1). Although there was a trend towards higher urinary excretion of riboflavin in the highriboflavin infected group, the difference was not statistically significant, probably because of smaller sample size (due to physical constraints, only three pooled urine samples (six animals) could be collected from this group).

Erythrocyte FMN and FAD levels were significantly lower in the low-riboflavin-fed group when compared with those of the high-riboflavin-fed group. During infection, FAD and total flavin (free riboflavin, FMN and FAD) levels were significantly higher in erythrocytes from both low- and high-riboflavin-fed groups (Table 2).

After recovery from infection, only erythrocyte total flavins were measured and the values were similar to those of the corresponding uninfected groups (Table 2).

EGR-AC values reflected the changes observed in the erythrocyte FAD levels. In the lcow-riboflavin-fed group, EGR-AC values were lower during infection but after recovery from infection they were similar to those for the corresponding uninfected group. Infection had no effect on the EGR-AC values in the high-riboflavin-fed group (Table 2).

Hepatic free riboflavin, FMN and FAD levels at 3 weeks (period 1) were 58, 44 and $24 \%$ lower respectively in the mice fed on the low-riboflavin diet when compared with those for mice fed on the high-riboflavin diet (Table 3). Total flavin and FAD levels were significantly lower during infection in the low- and high-riboflavin-fed animals when compared with values for the corresponding controls (Table 3). Infection did not affect free riboflavin and FMN levels.

Liver FAD levels after recovery from infection were similar to those of the corresponding controls (Table 3), whereas total flavin levels continued to be lower in the low-riboflavin infected group when compared with those for the corresponding uninfected control group (Table 3).

\section{Flavokinase}

Flavokinase activity was $50 \%$ lower in the mice fed on the low-riboflavin diet compared with the high-riboflavin diet at 3 weeks (period 1). No further changes were observed at 
Table 1. Effect of infection with Klebsiella pneumoniae on body weight and urinary riboflavin of mice fed on high- and low-riboflavin diets*

(Mean values with their standard errors)

\begin{tabular}{|c|c|c|c|c|c|c|c|c|c|c|c|c|}
\hline & \multicolumn{6}{|c|}{ Low riboflavin } & \multicolumn{6}{|c|}{ High riboflavin } \\
\hline & \multicolumn{3}{|c|}{ Uninfected } & \multicolumn{3}{|c|}{ Infected } & \multicolumn{3}{|c|}{ Uninfected } & \multicolumn{3}{|c|}{ Infected } \\
\hline & $n$ & Mean & $\mathrm{SE}$ & $n$ & Mean & $\mathbf{S E}$ & $n$ & Mean & $\mathrm{SE}$ & $n$ & Mean & $\mathbf{S E}$ \\
\hline \multicolumn{13}{|l|}{ Body wt (g) } \\
\hline Period 1 & 16 & $18 \cdot 67^{\mathrm{ax}}$ & 0.48 & 16 & $17 \cdot 78^{\mathrm{ax}}$ & 0.48 & 16 & $24 \cdot 03^{\mathrm{bx}}$ & 0.52 & 16 & $22 \cdot 86^{\mathrm{bx}}$ & 0.32 \\
\hline Period 2 & 14 & $21 \cdot 41^{a y}$ & 0.79 & 16 & $20 \cdot 77^{\text {ay }}$ & $0 \cdot 49$ & 14 & $28 \cdot 08^{\text {by }}$ & 0.75 & 14 & $29 \cdot 28^{\text {by }}$ & 0.52 \\
\hline \multicolumn{13}{|l|}{$\begin{array}{l}\text { Urinary riboflavin } \\
\text { (nmol/g creatinine) }\end{array}$} \\
\hline Period 1 & $6 \dagger$ & $4 \cdot 17^{a}$ & $0 \cdot 40$ & $6 \dagger$ & $24 \cdot 91^{\mathrm{b}}$ & $5 \cdot 28$ & $3 \dagger$ & $51.97^{\mathrm{e}}$ & $2 \cdot 82$ & $3 \dagger$ & $62 \cdot 80^{\mathrm{e}}$ & $3 \cdot 80$ \\
\hline
\end{tabular}

a, b.c Mean values with unlike superscript letters were significantly different between groups $(P<0 \cdot 05)$.

$x, y$ Mean values with unlike superscript letters were significantly different between periods $(P<0.05)$.

Period 1, during peak period of infection; period 2, after recovery.

* For details of experimental procedures, see pp. 454455.

$\uparrow$ No. of pooled samples where each sample represents two animals.

Table 2. Effect of infection with Klebsiella pneumoniae on erythrocyte flavin and the activation coefficient (stimulated: basal activity $A C$ ) of erythrocyte glutathione reductase (EC 1.6.4.2; EGR) in mice fed on high-and low-riboflavin diets*

(Mean values with their standard errors; $n$ represents pooled samples where each sample represents two animals)

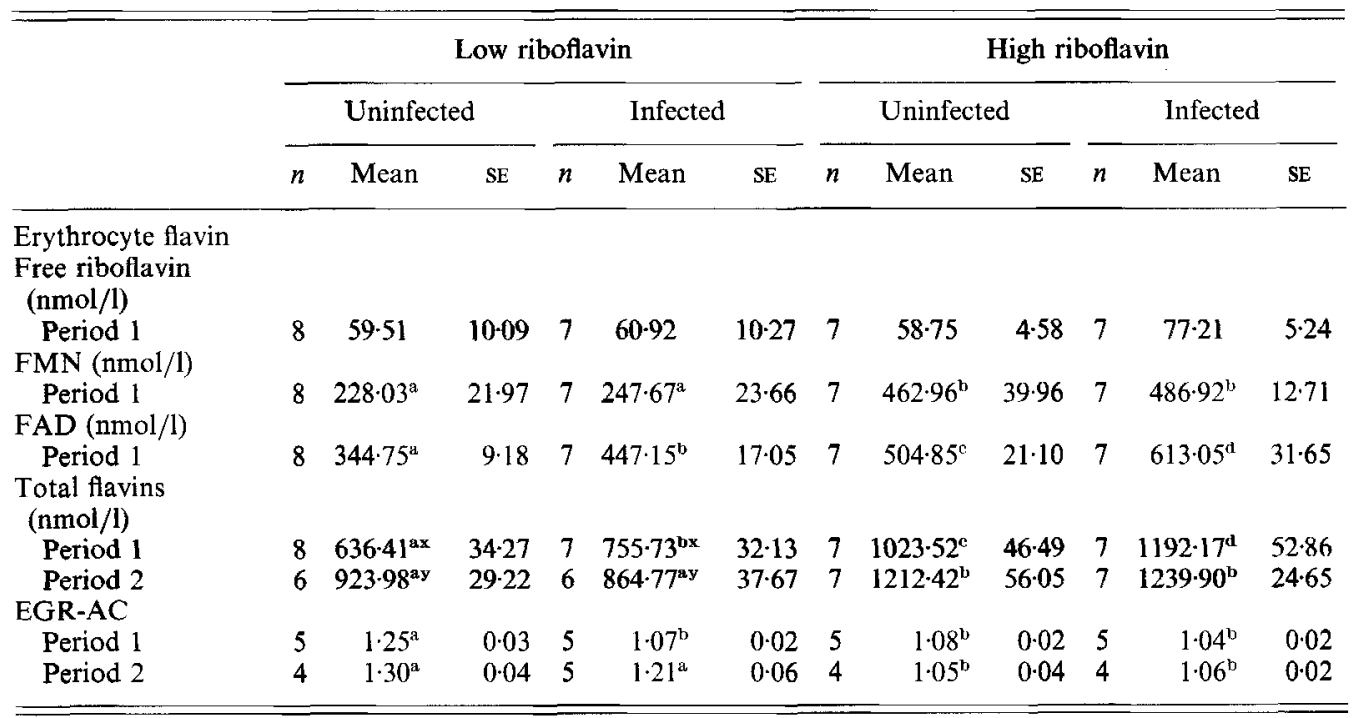

a, b, c, d Mean values with unlike superscript letters were significantly different between groups $(P<0.05)$.

x. y Mean values with unlike superscript letters were significantly different between periods $(P<0.05)$.

Period 1, during peak period of infection; period 2, after recovery.

* For details of experimental procedures, see pp. 454455. 
Table 3. Effect of infection with Klebsiella pneumoniae on liver flavins of mice fed on high- and low-riboflavin diets*

(Mean values with their standard errors; $n$ represents pooled samples where each sample represents two animals)

\begin{tabular}{|c|c|c|c|c|c|c|c|c|c|c|c|c|}
\hline & \multicolumn{6}{|c|}{ Low riboflavin } & \multicolumn{6}{|c|}{ High riboflavin } \\
\hline & \multicolumn{3}{|c|}{ Uninfected } & \multicolumn{3}{|c|}{ Infected } & \multicolumn{3}{|c|}{ Uninfected } & \multicolumn{3}{|c|}{ Infected } \\
\hline & $n$ & Mean & SE & $n$ & Mean & $\mathrm{SE}$ & $n$ & Mean & $\mathrm{SE}$ & $n$ & Mean & SE \\
\hline \multicolumn{13}{|c|}{$\begin{array}{l}\text { Free riboflavin } \\
\text { (nmol/g tissue) }\end{array}$} \\
\hline Period 1 & 7 & $1.43^{\mathrm{a}}$ & $0 \cdot 23$ & 8 & $1 \cdot 23^{\mathrm{a}}$ & 0.09 & 8 & $3.45^{b}$ & $0 \cdot 15$ & 8 & $4 \cdot 02^{b}$ & $0 \cdot 24$ \\
\hline Period 2 & 7 & $2 \cdot 24^{\mathrm{a}}$ & 0.25 & 7 & $2 \cdot 12^{\mathrm{a}}$ & $0-22$ & 8 & $3 \cdot 80^{b}$ & 0.57 & 8 & $3 \cdot 38^{\mathrm{b}}$ & $0 \cdot 37$ \\
\hline \multicolumn{13}{|c|}{ FMN (nmol/g tissue) } \\
\hline Period 1 & 7 & $15 \cdot 73^{a x}$ & 0.96 & 8 & $17 \cdot 05^{\mathrm{a}}$ & 1.90 & 8 & $28 \cdot 09^{b}$ & 1.71 & 8 & $28 \cdot 14^{\mathrm{h}}$ & $2 \cdot 25$ \\
\hline Period 2 & 7 & $25 \cdot 98^{\mathrm{ay}}$ & $1 \cdot 33$ & 7 & $21 \cdot 63^{\mathrm{a}}$ & 0.75 & 8 & $34 \cdot 20^{\mathrm{b}}$ & $1 \cdot 73$ & 8 & $29 \cdot 84^{\mathrm{b}}$ & 0.91 \\
\hline \multicolumn{13}{|c|}{ FAD (nmol/g tissue) } \\
\hline Period 1 & 7 & $34 \cdot 10^{a}$ & 1.59 & 8 & $26 \cdot 14^{\mathrm{b}}$ & $1 \cdot 11$ & 8 & $44 \cdot 78^{e}$ & $2 \cdot 25$ & 8 & $35.42^{\mathrm{a}}$ & 1.93 \\
\hline Period 2 & 7 & $33 \cdot 57^{a}$ & 1.06 & 7 & $31 \cdot 29^{\mathrm{a}}$ & 1.42 & 8 & $43 \cdot 31^{\mathrm{b}}$ & $2 \cdot 31$ & 8 & $40 \cdot 95^{b}$ & $1 \cdot 24$ \\
\hline \multicolumn{13}{|c|}{$\begin{array}{l}\text { Total flavins } \\
\text { (nmol/g tissue) }\end{array}$} \\
\hline Period 1 & 7 & $50.89^{a x}$ & $2 \cdot 26$ & 8 & $44 \cdot 41^{\mathrm{bx}}$ & $2 \cdot 42$ & 8 & $76 \cdot 36^{c}$ & $3 \cdot 30$ & 8 & $67 \cdot 60^{d}$ & $2 \cdot 33$ \\
\hline Period 2 & 7 & $62 \cdot 01^{8 \mathrm{y}}$ & 3.40 & 7 & $55.05^{\text {by }}$ & 1.78 & 8 & $80 \cdot 48^{c}$ & 1.89 & 8 & $74 \cdot 18^{c}$ & 1.95 \\
\hline
\end{tabular}

a, b, c, d Mean values with unlike superscript letters were significantly different between groups $(P<0.05)$.

$\mathrm{x}_{1} \mathrm{y}$ Mean values with unlike superscript letters were significantly different between periods $(P<0.05)$.

Period 1, during peak period of infection; period 2, after recovery.

* For details of experimental procedures, see pp. $454-455$.

5 weeks (period 2). During infection, flavokinase activity of the low-riboflavin-fed mice was $42 \%$ lower than that of the corresponding uninfected mice. There was no comparable change in activity in the high-riboflavin-fed animals. After recovery from infection the flavokinase activity of the low-riboflavin-fed group was significantly higher than that of the corresponding uninfected group (Table 4).

\section{FAD synthetase}

Riboflavin restriction per se resulted in higher enzyme activity at 3 weeks as well as at 5 weeks (periods 1 and 2 respectively). During infection the FAD synthetase activity of the low-riboflavin-fed group was $70 \%$ higher and that of the high-riboflavin-fed group $90 \%$ higher than that of their respective uninfected control group. After recovery the enzyme activities were similar to those of the corresponding uninfected control groups (Table 4).

\section{FMN (acid) phosphatase}

The FMN (acid) phosphatase activity was not affected by either the riboflavin content of the diet or infection (Table 4).

\section{FAD (nucleotide) pyrophosphatase}

The enzyme activity was $30 \%$ higher in the low-riboflavin-fed group when compared with high-riboflavin-fed group at 3 weeks (period 1). There was an age-related rise in the activity 
Table 4. Effect of infection with Klebsiella pneumoniae on flavin-metabolizing enzymes in the liver of mice fed on high-and low-riboflavin diets*

(Mean values with their standard errors; $n$ represents pooled samples where each sample represents two animals)

\begin{tabular}{|c|c|c|c|c|c|c|c|c|c|c|c|c|}
\hline & \multicolumn{6}{|c|}{ Low riboflavin } & \multicolumn{6}{|c|}{ High riboflavin } \\
\hline & \multicolumn{3}{|c|}{ Uninfected } & \multicolumn{3}{|c|}{ Infected } & \multicolumn{3}{|c|}{ Uninfected } & \multicolumn{3}{|c|}{ Infected } \\
\hline & $n$ & Mean & $\mathbf{S E}$ & $n$ & Mean & $\mathrm{SE}$ & $n$ & Mean & SE & $n$ & Mean & $\mathbf{S E}$ \\
\hline \multicolumn{13}{|c|}{$\begin{array}{l}\text { Flavokinase } \dagger \\
\text { (units } \ddagger / m g \text { protein) }\end{array}$} \\
\hline Period 1 & 8 & $5 \cdot 14^{u}$ & 0.43 & 8 & $3 \cdot 00^{\mathrm{bx}}$ & 0.32 & 5 & $9 \cdot 08^{\circ}$ & 0.47 & 4 & $8 \cdot 44^{\mathrm{c}}$ & 0.96 \\
\hline Period 2 & 6 & $5 \cdot 05^{\mathrm{a}}$ & 0.63 & 5 & $6 \cdot 77^{\text {by }}$ & 0.29 & 4 & $10 \cdot 10^{c}$ & 0.52 & 3 & $10 \cdot 58^{c}$ & 0.38 \\
\hline \multicolumn{13}{|c|}{$\begin{array}{l}\text { FAD synthetase } \S \\
\text { (units } \| / \mathrm{mg} \text { protein) }\end{array}$} \\
\hline Period 1 & 8 & $1 \cdot 35^{a}$ & 0.13 & 7 & $2 \cdot 31^{b x}$ & 0.11 & 4 & $1.02^{\mathrm{c}}$ & 0.09 & 4 & $1.94^{d}$ & 0.17 \\
\hline Period 2 & 5 & $1.37^{2}$ & 0.08 & 5 & $1 \cdot 20^{\text {ay }}$ & $0 \cdot 10$ & 3 & $0 \cdot 82^{b}$ & 0.08 & 3 & $0.98^{\mathrm{ab}}$ & 0.07 \\
\hline \multicolumn{13}{|c|}{$\begin{array}{l}\text { FMN (acid) phosphatase } \\
\text { (units**/mg protein) }\end{array}$} \\
\hline Period 1 & 8 & $978 \cdot 80$ & $38 \cdot 41$ & 8 & 894.94 & $43 \cdot 18$ & 5 & 993.62 & $44 \cdot 31$ & 4 & $1043 \cdot 60$ & $78 \cdot 41$ \\
\hline Period 2 & 5 & $875 \cdot 37$ & $94 \cdot 34$ & 5 & $949 \cdot 10$ & $73 \cdot 32$ & 3 & $947 \cdot 64$ & $131 \cdot 27$ & 3 & 998.94 & $83 \cdot 17$ \\
\hline \multicolumn{13}{|c|}{$\begin{array}{l}\text { FAD (nucleotide) pyrophosphatase } \dagger \dagger \\
\text { (units } \ddagger \ddagger / \text { mg protein) }\end{array}$} \\
\hline Period 1 & 6 & $7 \cdot 35^{\mathrm{a}}$ & 0.41 & 7 & $11 \cdot 11^{b}$ & 0.81 & 7 & $5 \cdot 51^{\mathrm{ox}}$ & 0.19 & 6 & $10 \cdot 83^{\mathrm{b}}$ & 0.58 \\
\hline Period 2 & 7 & $9 \cdot 79^{\mathrm{a}}$ & 0.56 & 7 & $11 \cdot 17^{\mathrm{a}}$ & 0.53 & 6 & $11 \cdot 49^{\mathrm{ay}}$ & 0.71 & 6 & $10 \cdot 54^{\mathrm{a}}$ & 0.79 \\
\hline
\end{tabular}

$\mathrm{a}, \mathrm{b}, \mathrm{e}, \mathrm{d}$ Mean values with unlike superscript letters were significantly different between groups $(P<0 \cdot 05)$.

$\mathrm{x}, \mathrm{y}$ Mean values with unlike superscript letters were significantly different between periods $(P<0 \cdot 05)$.

Period 1, during peak period of infection; period 2, after recovery.

* For details of experimental procedures, see pp. 454-455.

$\dagger$ ATP: riboflavin $5^{\prime}$-phosphotransferase (EC 2.7.1.26).

\$ One unit represents the formation of $1 \mathrm{nmol} F M N / 30 \mathrm{~min}$ at $37^{\circ}$.

$\S$ ATP: FMN adenylyltransferase (EC 2.7.7.2).

$\|$ One unit represents the formation of $1 \mathrm{nmol} F A D / 60 \mathrm{~min}$ at $37^{\circ}$.

I EC 3.1.3.2.

** One unit represents the formation of $1 \mathrm{nmol}$ riboflavin $/ 30 \mathrm{~min}$ at $37^{\circ}$.

†† EC 3.6.1.9.

ł. One unit represents the formation of $1 \mathrm{pmol} F \mathrm{FN} / \mathrm{min}$ at $37^{\circ}$.

of this enzyme. During infection the enzyme activities of the low- and high-riboflavin-fed groups were respectively 50 and $96 \%$ higher than those of their respective controls (period 1). At 5 weeks (period 2), FAD (nucleotide) pyrophosphatase activities were similar for all four groups (Table 4).

\section{Plasma triiodothyronine and thyroxine}

The low-riboflavin diet did not alter plasma T3 and T4 levels at 3 weeks (period 1), but at 5 weeks (period 2), plasma T4 levels of the low-riboflavin-fed group were $45 \%$ lower than those of the high-riboflavin-fed group. During infection, plasma T3 levels of the lowriboflavin-fed group were $25 \%$ lower and those of the high-riboflavin-fed group were $23 \%$ lower than those of their respective controls. Infection had no effect on plasma T4 concentration. After recovery from infection, T3 levels were similar to those of the corresponding uninfected controls (Table 5). 
Table 5. Effect of infection with Klebsiella pneumoniae on thyroid hormone status of mice fed on high- and low-riboflavin diets*

(Mean values with their standard errors; $n$ represents pooled samples where each sample represents two animals)

\begin{tabular}{|c|c|c|c|c|c|c|c|c|c|c|c|c|}
\hline & \multicolumn{6}{|c|}{ Low riboflavin } & \multicolumn{6}{|c|}{ High riboflavin } \\
\hline & \multicolumn{3}{|c|}{ Uninfected } & \multicolumn{3}{|c|}{ Infected } & \multicolumn{3}{|c|}{ Uninfected } & \multicolumn{3}{|c|}{ Infected } \\
\hline & $n$ & Mean & $\mathrm{SE}$ & $n$ & Mean & $\mathrm{SE}$ & $n$ & Mean & SE & $n$ & Mean & SE \\
\hline \multicolumn{13}{|c|}{$\begin{array}{l}\text { Plasma triiodothyronine } \\
(\mathrm{nmol} / \mathrm{l})\end{array}$} \\
\hline Period 1 & 7 & $2 \cdot 88^{\mathrm{a}}$ & 0.26 & 8 & $1.97^{\mathrm{b}}$ & 0.09 & 7 & $2 \cdot 54^{\mathrm{a}}$ & $0 \cdot 13$ & 7 & $1.95^{\mathrm{b}}$ & 0.08 \\
\hline Period 2 & 7 & $2 \cdot 67$ & 0.16 & 7 & $2 \cdot 55$ & $0 \cdot 12$ & 8 & $2 \cdot 43$ & $0 \cdot 16$ & 7 & $2 \cdot 47$ & 0.15 \\
\hline \multicolumn{13}{|c|}{$\begin{array}{l}\text { Plasma thyroxine } \\
(\mathrm{nmol} / 1)\end{array}$} \\
\hline Period 1 & 8 & $27 \cdot 19$ & $3 \cdot 75$ & 8 & 27.99 & $4 \cdot 25$ & 8 & $33 \cdot 85^{x}$ & $4 \cdot 25$ & 8 & $26 \cdot 66^{x}$ & $2 \cdot 73$ \\
\hline Period 2 & 8 & $28 \cdot 68^{a}$ & 3.61 & 7 & $34 \cdot 02^{y}$ & $5 \cdot 74$ & 7 & $50 \cdot 75^{\text {by }}$ & $3 \cdot 35$ & 6 & $38 \cdot 37^{a y}$ & $4 \cdot 23$ \\
\hline
\end{tabular}

a, b Mean values with unlike superscript letters were significantly different between groups $(P<0.05)$.

$x, y$ Mean values with unlike superscript letters were significantly different between periods $(P<0.05)$.

Period 1, during peak period of infection; period 2, after recovery.

* For details of experimental procedures, see pp. $453-455$.

\section{DISCUSSION}

The results of the present study for the low-riboflavin infected group confirm the earlier observations made in children that respiratory infection raises the level of riboflavin in blood and urine (Bamji et al. 1987).

The increase in erythrocyte flavin was associated with the major metabolite, FAD. This would explain the reduction in EGR-AC reported previously (Bamji et al. 1987; Padmaja et al. 1991), as well as that found in the present study.

Reduction in total flavin and FAD levels during infection suggests a shift of riboflavin from tissues into the circulation, facilitating its elimination through urine during infection. The data on enzyme activities provide some insight into the mechanism(s) involved.

The low-riboflavin diet per se was found to lower the activity of flavokinase, the first enzyme of the pathway towards FAD synthesis. A similar finding has been reported by other workers (Fass \& Rivlin, 1969; Prentice \& Bates, 1981; Lee \& McCormick, 1983) and may be due to instability of the enzyme in the absence of the substrate (Rivlin \& Langdon, 1966; Fass \& Rivlin, 1969).

Klebsiella pneumoniae infection affected flavokinase but only in the low-riboflavin-fed group. This effect may be due to lower plasma T3 levels. This hormone is known to convert the less-active form of flavokinase to a more-active form (Lee \& McCormick, 1985). Reductions in plasma T3 levels were also reported during respiratory infection in children (Hashimoto et al. 1994) and bacterial infection in mice (Burgi et al. 1986) and this was attributed to increases in cytokines such as tumour necrosis factor (TNF)- $\alpha$, interleukins (IL)-1 and -6 (Hashimoto et al. 1994). Injection of TNF- $\alpha$ (Pang et al. 1989) or IL-1 (Fujii et al. 1989) resulted in a reduction in plasma thyroid hormone levels in animals.

In contrast to flavokinase, FAD synthetase levels tended to be higher in riboflavinrestricted mice as well as in infected mice. This could have been a compensatory effect to maintain liver FAD levels, but the increase in the enzyme activity was probably not sufficient to compensate, since FAD levels were lowered. The reported effects of riboflavin deficiency on FAD synthetase are variable (Fass \& Rivlin, 1969; Prentice \& Bates, 1981; 
Lee \& McCormick, 1983). Fass \& Rivlin (1969) observed a peak increase in the FAD synthetase activity after $50 \mathrm{~d}$ of riboflavin deficiency. A similar increase in the activity of this enzyme was also observed by Prentice \& Bates (1981) after 3 weeks of riboflavin deficiency. However, Lee \& McCormick (1983) observed a moderate decrease in the activity of this enzyme after 5 weeks of riboflavin deficiency in rats.

While neither riboflavin restriction nor infection affected FMN (acid) phosphatase activity, FAD (nucleotide) pyrophosphatase levels were significantly increased by infection in the riboflavin-restricted group as well as in the high-riboflavin-fed groups compared with values for the uninfected controls.

An earlier study using a similar experimental design showed that infection lowered the activity of the hepatic FAD-dependent mitochondrial enzyme acyl-CoA dehydrogenase, but not that of D-amino acid oxidase (EC 1.4.3.3), whereas the activity of FMNdependent pyridoxamine-phosphate oxidase increased (Padmaja et al. 1991). These observations can be explained on the basis of the changes in FAD and FMN levels reported in the present study. The fall in liver FAD levels during infection observed in the present study may explain the reduction in acyl-CoA dehydrogenase which has been shown to be one of the most sensitive flavin enzymes to riboflavin deficiency (Hoppel et al. 1979). A more-severe deficiency may be required to bring about a change in D-amino acid oxidase which is relatively less-sensitive to riboflavin deficiency. Although FMN-dependent pyridoxamine-phosphate oxidase showed an increase in activity, FMN levels were unchanged during infection. The increase in pyridoxamine-phosphate oxidase could be a response to the greater demand for pyridoxal phosphate to metabolize the amino acids liberated as a result of the catabolic effect of infection.

It is possible that respiratory infections inhibit the synthesis of some FAD-dependent flavoproteins, making free FAD available for enzymic degradation. The higher FAD (nucleotide) pyrophosphatase activity observed during infection could be a consequence of higher substrate availability or may be attributed to an independent factor. Reduction in flavokinase may further restrict the availability of riboflavin for coenzyme synthesis. The net effect would be a shift of riboflavin from the liver into the circulation. During infections the demand for riboflavin can be expected to go up in blood cells, particularly in the leukocytes, to sustain some of the oxidation-reduction reactions mediated by FADdependent enzymes, such as glutathione reductase and NADPH oxidase. The observed shift of riboflavin from the liver into the circulation may be in response to this demand. In severe riboflavin deficiency this process may be impaired and the defence system compromised. Indeed, in one of our earlier studies phagocytic activity by peritoneal leukocytes was reduced in riboflavin-deficient rats (Lakshmi et al. 1994).

Thus, it may be concluded that respiratory infections would exacerbate riboflavin deficiency in a population already suffering from dietary deficiency of this vitamin.

The authors are grateful to Dr G. Radhaiah for his valuable guidance in the statistical analysis of the data.

\section{REFERENCES}

Ahmed, F., Jacob, C. M. \& Bamji, M. S. (1981). Enzymatic measurement of tissue flavin adenine dinucleotide using rat kidney apo D-amino acid oxidase. Indian Journal of Medical Research 73, 404-409.

Bamji, M. S., Arya, S., Rameshwar Sarma, K. V. \& Radhaiah, G. (1982). Impact of long term, low dose B complex vitamin supplements on vitamin status and psychomotor performance of rural school boys. Nutrition Research 2, 147-153.

Bamji, M. S., Bhaskaram, P. \& Jacob, C. M. (1987). Urinary riboflavin excretion and erythrocyte glutathione reductase activity in preschool children suffering from upper respiratory infections and measles. Annals of Nutrition and Metabolism 31, 191-196. 
Bamji, M. S. \& Prema, K. (1981). Enzymatic riboflavin and pyridoxine deficiencies in young Indian women suffering from different grades of glossitis. Nutrition Reports International 24, 649-658.

Bamji, M. S., Rameshwar Sarma, K. V. \& Radhaiah, G. (1979). Relationship between biochemical and clinical indices of B vitamin deficiency. A study in rural school boys. British Journal of Nutrition 41, 431-441.

Bates, C. J., Prentice, A. M., Paul, A. A., Sutcliffe, B. A., Watkinson, M. \& Whitehead, R. G. (1981). Riboflavin status in Gambian pregnant and lactating women and its implication for recommended dietary allowance. American Journal of Clinical Nutrition 34, 928935.

Batey, D. W. \& Eckhert, C. D. (1990). Identification of FAD, FMN and riboflavin in the retina by microextraction and high performance liquid chromatography. Analytical Biochemistry 188, 164-167.

Bayoumi, R. A. \& Rosalki, S. B. (1976). Evaluation of methods of coenzyme activation of erythrocyte enzymes for detection of deficiency of vitamins $B_{1}, B_{2}$ and $B_{6}$. Clinical Chemistry 22, 327-335.

Burgi, U., Feller, C. \& Gerber, A. U. (1986). Effects of an acute bacterial infection on serum thyroid hormones and nuclear triiodothyronine receptors in mice. Endocrinology 119, 515-521.

Fass, S. \& Rivlin, R. S. (1969). Regulation of riboflavin-metabolizing enzymes in riboflavin deficiency. American Journal of Physiology 217, 988-991.

Fujii, T., Sato, K., Ozawa, M., Kasono, K., Imamura, H., Kanaji, Y., Tsushima, T. \& Shizume, K. (1989). Effect of interleukin-1(IL-1) on thyroid hormone metabolism in mice: stimulation by IL-1 of iodothyronine $5^{\prime}$ deiodinating activity (type 1) in the liver. Endocrinology 124, 167-174.

Hashimoto, H., Igarashi, N., Yachie, A., Miyawaki, T. \& Tomotou, S. (1994). The relationship between serum levels of IL-6 and thyroid hormone in children with acute respiratory infection. Journal of Clinical Endocrinology and Metabolism 78, 288-291.

Hoppel, C., Dimarco, J. P. \& Tandler, B. (1979). Riboflavin and rat hepatic cell structure and function. Journal of Biological Chemistry 254, 4164-4170.

Kearney, E. B. \& Englard, S. (1951). The enzymatic phosphorylation of riboflavin. Journal of Biological Chemistry $193,821-834$.

Krishnan, N. \& Appaji Rao, N. (1972). Studies on nucleotide pyrophosphatase 1. Partial purification and properties of a sheep liver enzyme that catalyzes the hydrolysis of dinucleotides. Archives of Biochemistry and Biophysics 149, 336-348.

Lakshmi, R., Lakshmi, A. V. \& Bamji, M. S. (1994). Phagocytosis in riboflavin - or pyridoxine deficient mice. Journal of Nutritional Biochemistry 5, 189-192.

Lee, S. \& McCormick, D. B. (1983). Effect of riboflavin status on hepatic activities of flavin-metabolizing enzymes in rats. Journal of Nutrition 113, $2274-2279$.

Lee, S. \& McCormick, D. B. (1985). Thyroid hormone regulation of flavocoenzyme biosynthesis. Archives of Biochemistry and Biophysics 237, 197-201.

Lowry, O. H., Rosebrough, N. J., Farr, A. L. \& Randall, R. J. (1951). Protein measurement with the folin phenol reagent. Journal of Biological Chemistry 193, 265-275.

McCormick, D. B. (1961). Flavokinase activity of rat tissues and masking effect of phosphatases. Proceedings of the Society of Experimental Biology and Medicine 107, 784-786.

McCormick, D. B. (1964). Inhibition of flavin adenine dinucleotide pyrophosphorylase by isoriboflavin. Nature 201, 925-926.

Merrill, A. H. \& McCormick, D. B. (1980). Affinity chromatographic purification and properties of flavokinase (ATP: Riboflavin 5'-phosphotransferase) from rat liver. Journal of Biological Chemistry 255, $1335-1338$.

Morell, D. B. \& Slater, E. C. (1946). The fluorimetric determination of riboflavin in urine. Biochemical Journal 40 , 652-657.

Ohkawa, H., Ohishi, N. \& Yagi, K. (1983). Hydroxylation of the 7- and 8-methyl groups of riboflavin by the microsomal electron transfer system of rat liver. Journal of Biological Chemistry 258, 5629-5633.

Oser, B. L. (1965). In Hawk's Physiological Chemistry, Fourteenth Edition, p. 1233. [B. L. Oser, editor]. New York: The Blakiston Division McGraw-Hill Book Company.

Padmaja, P. A., Lakshmi, A. V., Suresh, P. \& Bamji, M. S. (1991). Effect of respiratory infection on tissue riboflavin and flavin enzymes in mice. Annals of Nutrition and Metabolism 35, 19-24.

Pang, X. P., Hershman, J. M., Mirell, C. J. \& Pekary, A. E. (1989). Impairment of hypothalamic-pituitary-thyroid function in rats treated with human recombinant tumor necosis factor- $\alpha$ (cachectin). Endocrinology $125,7684$.

Prentice, A. M. \& Bates, C. J. (1981). A biochemical evaluation of the erythrocyte glutathione reductase (EC 1 6.4.2) test for riboflavin status. British Journal of Nutrition 45, 37-52.

Rivlin, R. S. \& Langdon, R. G. (1966). Regulation of hepatic FAD levels by thyroid hormone. In Advances in Enzyme Regulation, vol. 4, pp. 45-58. [G. Weber, editor]. Oxford: Pergamon Press.

Snedecor, G. W. \& Cochran, W. G. (1967). Statistical Methods, 6th ed., pp. 299-334. Oxford: IBH Publishing Co.

Thurnham, D. L., Migasena, P., Vudhival, N. \& Supawan V. (1971). A longitudinal study on dietary and social influences on riboflavin status in pre-school children in North-East Thailand. Southeast Asian Journal of Tropical Medicine and Public Health 2, 552-563.

World Health Organization Task Force and Oral Contraceptives (1986). Impact of hormonal contraceptives vis$a$-vis non-hormonal factors on the vitamin status of malnourished women in India and Thailand. Human Nutrition: Clinical Nutrition 40 C, 205-220. 